\title{
PROSES PENANGGUHAN PENAHANAN DENGAN JAMINAN PADA TINGKAT PENYIDIK BERDASARKAN PASAL 31 KUHAP
}

\author{
I Made Arya Kusuma Winata, I Nyoman Gede Sugiartha \& I Made Minggu Widyantara \\ Fakultas Hukum Universitas Warmadewa, Denpasar-Bali, Indonesia \\ madearyakusumawinata@gmail.com, nyomansugiartha14@gmail.com, \\ mademinggu21@gmail.com
}

\begin{abstract}
Abstrak
Hukum bukanlah sekedar pedoman untuk dilihat dan dibaca atau diketahui saja, melainkan untuk dilaksanakan dan ditaati, dari segala peraturan hukum adalah bersifat mengatur dan memaksa anggota masyarakat untuk patuh mentaatinya, sehingga keseimbangan tiap-tiap hubungan dalam masyarakat dapat dicapai. Tujuan dari penelitian ini adalah untuk menganalisa syarat dan prosedur yang harus dipenuhi pemohon agar dapat dilakukannya penangguhan penahanan dan dasar pertimbangan bagi penyidik untuk menangguhkan penahanan dengan jaminan. Penelitian ini menggunakan metode normatif pada peraturan perundang-undangan, teori hukum dan pendapat sarjana. Dari penelitian ini ditemukan bahwa persyaratan dan prosedur yang harus dipenuhi pemohon agar dapat dilakukan penangguhan dan penahanan adalah penahanan harus ditetapkan oleh instansi Kepolisian yang menahan dan dasar pertimbangan bagi penyidik untuk menangguhkan penahanan dengan jaminan adalah Pasal 31 ayat (1) UU No. 8 Tahun 1981 tentang Hukum Acara Pidana (KUHAP).
\end{abstract}

Kata kunci: Penahanan, Penangguhan, Penyidik, dan Pasal 31 KUHP

\begin{abstract}
Law is not just a guide to be seen and read or known, but to be implemented and obeyed, of all legal regulations are of a regulatory nature and force members of society to obey them, so that the balance of every relationship in society can be achieved. The purpose of this research is to analyze the requirements and procedures that must be met by the applicant in order to carry out a suspension of detention and the basis for the investigators to suspend detention on bail. This research uses normative methods in statutory regulations, legal theory and undergraduate opinion. The researcher found out that he requirements and procedures that must be fulfilled by the applicant in order for a suspension and detention to be carried out are that detention must be determined by the detaining Police agency and the basis for consideration for investigators to postpone detention on guarantee is Article 31 paragraph (1) of Law No. 8 of 1981 concerning Criminal Procedure Law.
\end{abstract}

Keywords: Suspension, Detention, and Investigators

\section{PENDAHULUAN}

Indonesia adalah Negara yang berdasarkan hukum, hal ini diartikan bahwa pemerintah dan lembaga negara harus dapat dipertanggung jawabkan secara hukum (Kansil, 2007:22). Negara hukum dalam arti luas dapat dikatakan sebagai negara hukum dalam arti materiil yang tidak sekedar melindungi segenap bangsa Indonesia dan seluruh tumpah darah Indonesia, namun negara hukum juga harus memajukan kesejahteraan umum dan mencerdaskan kehidupan bangsa.

Hukum dapat digolongkan menjadi beberapa bagian yang didasarkan pada sumbernya, berlakunya, tempat berlakunya, waktu berlakunya, cara mempertahankannya, sifat serta isi yang ada di dalamnya. Saat ini dimasyarakat hukum yang paling menonjol dilihat dari pelaksanaannya adalah hukum pidana yang dengan mekanisme formal hukum acara pidana. Namun pada pelaksanaannya hukum acara pidana terdapat dilema yang tampak bertentangan dengan penegakan HAM yaitu penahanan terhadap oknum warga negara yang disangka atau 
didakwa telah melakukan tindak pidana. Yang terpenting dari segala hukum ialah penggolongan hukum berdasarkan isinya, yaitu hukum privat dan hukum publik. Penahanan merupakan penempatan tersangka atau terdakwa yang hanya boleh dilakukan oleh penyidik, penuntut umum dan hakim. Untuk menjaga agar tidak merugikan karena adanya kemungkinan untuk ditahan cukup lama maka dalam hukum acara pidana diatur suatu ketentuan bahwa tersangka atau terdakwa dapat memohon penangguhannya untuk ditangguhkan (Berutu, 2017: 82-92).

Menurut Pasal 1 Angka 21 Kitab Undang-Undang Hukum Acara Pidana (KUHAP), penahanan adalah ditempatkannya tersangka atau terdakwa di tempat tertentu oleh penyidik, atau penuntut umum atau hakim dengan penetapannya, dalam hal serta menurut cara yang diatur dalam undang-undang ini. Status tahanan sering menjadi berkepanjangan karena proses pemeriksaan di pihak kepolisian masih berjalan. Disebutkan bahwa Penangguhan tahanan tersangka atau terdakwa dari penahanan yaitu mengeluarkan tersangka atau terdakwa dari penahanan sebelum masa atau waktu penahanannya berakhir (Harahap, 1988).

Penangguhan ini diatur dalam pasal 31 KUHAP. Bunyi pasal 31 KUHAP, adalah bahwa atas permintaan tersangka atau terdakwa, penyidik atau penuntut umum atau hakim, sesuai dengan kewenangan masing-masing, dapat mengadakan penangguhan penahanan dengan atau tanpa jaminan uang atau jaminan orang berdasarkan syarat yang ditentukan (Giraldo, 2020:1). Sesuai pasal 31 tersebut dapat ditarik pengertian bahwa penangguhan tahanan tersangka atau terdakwa dari penahanan sebelum batas waktu penahanan berakhir, namun pelaksanaan dari penahanan masih harus dijalani tersangka atau terdakwa ditangguhkan, sekalipun masa penahanan yang diperintah kepadanya belum habis. Dengan adanya penangguhan penahanan seorang tersangka atau terdakwa dikeluarkan dari tahanan pada saat masa tahanan yang sah dan resmi sedang berjalan atau belum berakhir. Terkait dengan jaminan, KUHAP menjelaskan jaminan itu dapat berupa uang atau jaminan orang, namun besaran uang jaminan untuk mendapatkan penangguhan penahanan tidak diatur baik didalam KUHAP maupun peraturan pelaksanaan lainnya. Fenomena yang terjadi bahwa tersangka atau terdakwa sulit untuk mendapatkan penangguhan penahanan bahkan hanya orang-orang tertentu saja yang mendapatkan penangguhan dengan jaminan uang. Besaran uang jaminan bervariasi tergantung berapa besar kerugian negara yang ditimbulkan akibat perbuatan itu, disamping itu juga uang jaminan tidak dikembalikan kepada tersangka atau terdakwa.

Implementasi pasal 31 KUHP Tentang Penangguhan Penahanan Dengan Jaminan atau Tanpa Jaminan memberikan peluang bagi para pemohon untuk mengajukan penangguhan penahanan kepada hakim (Hafid, 2010). Dalam pemberian jaminan orang untuk penangguhan penahanan ini, harus menyertakan identitas orang yang menjadi jaminan agar apabila tahanan tidak kembali lebih dari 3 bulan maka orang yang menjadi jaminan harus menanggung prosedur yang telah ditetapkan (Auliani, 2017). Tapi dalam proses penangkapan tahanan tentunya tidak luput dari yang namanya problematika. Problematika ini muncul akibat adanya pasal 31 KUHAP yang masih memberikan peluang untuk melakukan penangguhan penahanan yang dapat memperngaruhi proses penangkapan itu sendiri (Hasriady \& Djanggih).

\section{METODE PENELITIAN}

Penelitian ini termasuk dalam jenis penelitian hukum normatif yang bersifat penjelajahan (ekspolaritas) dengan menggunakan bahan-bahan kepustakaan sebagi sumber data penelitian. Pendekatan masalah yang digunakan dalam penelitian ini adalah pendekatan yuridis normatif yang dilakukan dengan mempelajari teori-teori, konsep-konsep, serta peraturan yang berkaitan dengan permasalahan. Analisis data yang digunakan dalam penelitian ini adalah analisi kualitatif dengan menggunakan metode penguraian deskritif analitis, dimana menurut Ariandi (2018:1) metode tersebut menguraikan data yang diperoleh dan menghubungkannya satu sama lain untuk mendapatkan kesimpulan yang bersifat umum. 


\section{HASIL ANALISIS DAN PEMBAHASAN}

1. Persyaratan dan Prosedur yang Harus Dipenuhi Pemohon Penangguhan Penahanan Dalam Pasal 31 KUHAP, Penahanan atas diri tersangka/terdakwa dapat ditangguhkan pelaksanaannya oleh peyidik. Penuntut umum atau Hakim yang menahannya sesuai dengan kewenangan masing-masing. Penangguhan penahanan dilakukan dengan jaminan uang atau orang atau tanpa jaminan sama sekali. Syarat penangguhan penahanan harus ditetapkan oleh instansi Kepolisian yang menahan, tahanan yang bersangkutan menyatakan kesediaan untuk menaati, baru kemudian instansi Kepolisian yang berwenang memberi penangguhan. Masa penangguhan penahanan itu tidak termasuk masa status tahanan, oleh karena itu tidak dipotongkan dalam hukuman yang dijatuhkan.

Dalam Undang-Undang Nomor 27 Tahun 1983 Tentang Pelaksanaan Undang- Undang Hukum Acara Pidana diatur bahwa dalam permintaan penangguhan penahanan, ada jaminan yang disyaratkan yang bisa berupa: Jaminan uang (Pasal 35) dimana jaminan uang ini ditetapkan oleh pejabat yang berwenang sesuai dengan tingkat pemeriksaan dan disimpan di kepaniteraan pengadilan negeri dan jaminan orang (Pasal 36) dimana orang penjamin bisa penasihat hukumnya, keluarganya, atau orang lain yang tidak mempunyai hubungan apa pun dengan tahanan.

Disebutkan bahwa Penangguhan penahanan terjadi karena adanya asas praduga tak bersalah. Terjadinya penangguhan penahanan seolah-olah didasarkan pada bentuk kontrak atau perjanjian dalam hubungan perdata. Itu sebabnya cenderung untuk mengatakan terjadinya penangguhan penahanan berdasarkan perjanjian antara orang tahanan dengan pihak instansi yang menahan (Nurhasan, 2017:205-215).

Hakim menentukan apabila ada alasan untuk dapat memberikan penangguhan penahanan dengan ditentukan syarat-syaratnya adalah Terdakwa harus bersedia ditahan kalau perintah penundaannya dicabut; dan Terdakwa harus bersedia ditahan kalau ia dalam waktu penangguhan penahanan itu melakukan suatu perbuatan pidana yang ditentukan dalam Pasal 62 ayat 2 HIR (Syarat Multak) serta Terdakwa harus menyerahkan uang tanggungan atau barang berharga kepada pengadilan yang mengadilinya (Syarat Fakultatif) (Soesilo, 2013).

Pasal 31 KUHAP tidak mengatur prosedur penangguhan penahanan, pasal ini hanya mengatur adanya kewenangan untuk menangguhkan penahanan dengan atau tanpa uang jaminan atau orang dan kewenangan untuk mencabut penangguhan penahanan. Setelah dikabulkannya penangguhan penahanan dengan jaminan uang selanjutnya diadakan perjanjian antara pejabat yang berwenang sesuai dengan tingkat pemeriksaan dengan tersangka atau penasehat hukumnya beserta syarat-syarat yang harus dipenuhinya. Instansi atau pejabat yang berwenang dapat menetapkan jumlah besarnya uang yang harus dijadikan jaminan.

Penangguhan penahanan di dasari atas hukum yang diatur dalam Pasal 31 ayat (1) UU No. 8 Tahun 1981 tentang Hukum Acara Pidana (KUHAP) yang berbunyi, Atas permintaan tersangka atau terdakwa, penyidik atau penuntut umum atau hakim, sesuai dengan kewenangan masing-masing, dapat mengadakan penangguhan penahanan dengan atau tanpa jaminan uang atau jaminan orang, berdasarkan syarat yang ditentukan, (2) Karena jabatannya penyidik atau penuntut umum atau hakim sewaktuwaktu dapat mencabut penangguhan penahanan dalam hal tersangka atau tersangka atau terdakwa melanggar syarat sebagaimana dimaksud dalam ayat (1).

Mengenai syarat penangguhan penahanan pada penjelasan Pasal 31 ayat (1) KUHAP, tersangka/terdakwa (1) Wajib lapor. Wajib lapor merupakan salah satu syarat dalam penangguhan penahanan. Karena wajib lapor berhubungan dengan penahanan, maka ini berarti orang yang diwajibkan untuk melapor tersebut adalah tersangka atau terdakwa untuk melapor setiap hari, satu kali dalam setiap tiga hari atau satu kali seminggu, dan sebagainya. (2) Tidak keluar rumah. Tersangka/terdakwa tetap untuk berada di rumah selama masa penangguhan penahanan dengan mengadakan pengawasan untuk menghindarkan segala sesuatu yang dapat menimbulkan kesulitan dalam penyidikan, penuntutan atau pemeriksaan di sidang pengadilan. (3) Tidak keluar kota. Tidak dilakukan pengawasan langsung pada penahanan kota, namun mereka yang ditahan wajib melapor pada waktu-waktu yang telah ditentukan. 


\section{Pertimbangan Aparatur Penegak Hukum Ditingkat Penyidikan}

Sesuai dengan ketentuan Pasal 31 Kitab Undang-Undang Hukum Acara Pidana (KUHAP) Tentang Penangguhan Penahanan, suatu penagguhan penahanan dapat dimohonkan oleh semua tersangka atau terdakwa dengan jalan mengajukan permohonannya kepada instansi yang melakukan penahanan baik instansi kepolisian, kejaksaan maupun pengadilan yang dalam hal ini diwakili oleh hakim. Setelah permohonan tersebut diutarakan maka instansi yang berwenang mempertimbangkan apakah permohonan penangguhan penahanan dari tersangka atau terdakwa dikabulkan atau ditolak.

Aparatur penegak hukum yang menurut hukum mempunyai suatu kewajiban untuk memberitahukan serta menjelaskan hak-hak tersangka sebelum menjalani proses hukum acara pidana, seringkali mereka cenderung menghindari kewajibannya tersebut. Cara mereka menghindari kewajibannya tersebut yakni dengan tidak memberitahukan sama sekali atau membodohi tersangka atau terdakwa, memberitahukan namun disertai dengan ancaman (menakut-nakuti) dengan cara yang tidak simpatik, memberitahukan namun disertai dengan keterangan yang berkesan halus namun tidak jelas. Aparat penegak hukum dalam menegakkan hukum tidak terlepas akan suatu faktor-faktor yang mempengaruhinya, hal tersebut penting karena dalam menegakkan hukum, seorang polisi langsung berhadapan dengan masyarakat, sehingga dalam menegakkan hukum kadang polisi selaku aparat penegak hukum mempunyai masalah ataupun dampak positif serta negatif dalam menegakkan suatu norma positif di masyarakat.

Faktor penegak hukum merupakan salah satu faktor yang penting serta tidak bisa diabaikan begitu saja, sebab pengabaiannya faktor-faktor yang ada menyebabkan tidak tercapainya penegakan hukum yang diharapkan sesuai tujuan hukum tersebut. Aparat penegak hukum tidak boleh seenaknya untuk melakukan penahanan akan tetapi haruslah didasarkan pada pertimbangan hukum yang jelas atau paling tidak sebagaimana yang diatur dalam peraturan perundang-undangan yang berlaku. Penahanan dan penangguhan penahanan sudah diatur dalam Pasal 1 angka 21 Kitab Undang-Undang Hukum Acara Pidana (KUHAP) bahwa penahanan adalah penempatan tersangka atau terdakwa ditempat tertentu oleh penyidik atau penuntut umum atau hakim dengan penetapannya, dalam hal menurut cara yang diatur dalam undangundang ini.

Tindakan Penahanan oleh penyidik dengan pertimbangan bahwa penahanan dilakukan terhadap tersangka dalam hal adanya keadaan yang mengkhawatikan bahwa tersangka melarikan did atau menghilangkan barang bukti. Untuk dapat dilakukan penahanan, harus memenuhi syarat-syarat : Unsur Subyektif (Akan melarikan diri; Akan merusak atau menghilangkan barang bukti; mengulangi tindak pidana; mempengaruhi atau menghilangkan saksi) dan Unsur Objektif dimaana penahanan hanya dapat dilakukan atau dikenakan dalam hal tindak pidana yang diacamdengan hukuman penjara 5 tahun atau lebih; Tindak pidana terhadap pasal-pasal tertentu sebagaimana diatur dalam Pasal 21 ayat (4) KUHAP.

Kondisi dari tersangka atau terdakwa juga perlu diperhatikan dari aspek ekonomi agar nantinya dapat mencerminkfan adanya suatu keseimbangan, sebagai contoh misalnya bagi tersangka atau terdakwa yang kurang mampu maka penetapan jumlah uang jaminannya tidak terlalu besar begitu juga sebaliknya dengan tersangka/terdakwa yang kondisi ekonominya dapat dikatakan berkecukupan maka jumlah uang jaminannya nantinya jangan terlalu ringan. Pada dasarnya disesuaikan dengan kondisi yang ada dan kondisi kemampuan ekonomi dari tersangka/terdakwa sangat berperan terhadap kebijaksanaan dari pejabat yang menentukan besarnya uang jaminan penangguhan tersebut.

Besarnya jumlah uang jaminan yang ditetapkan dalam penetapan suatu penangguhan penahanan sepenuhnya merupakan kewenangan dan kebijaksanaan dari instansi yang mengabulkan penangguhan penahanan tersebut dan sudah tentu tidak terlepas dengan adanya kesepakatan antara instansi tersebut dengan pemohon penangguhan tersebut. Dengan tidak adanya suatu ketentuan manapun yang mengatur mengenai penetapan jumlah uang jaminan tersebut maka yang terjadi adalah adanya perbedaan rasa keadilan dimana dalam kasus yang 
serupa penetapan jumlah uang jaminan dapat berbeda-beda. Setelah dilakukan pertimbangan terkait alasan-alasan yang dikemukakan tersangka/terdakwa dan menetapkan besarnya jumlah uang jaminan dan menentukan syarat yang harus dipenuhi oleh tersangka/terdakwa maka instansi yang mengabulkan suatu permohonan penangguhan membuatkan suatu bentuk perjanjian penangguhan berupa berita acara penangguhan, surat perintah penangguhan maupun penetapan penangguhan penahanan.

Selama tersangka atau terdakwa tersebut mentaati seluruh syarat atau ketentuan penangguhan penahanannya maka secara materil dan yuridis uang jaminan tersebut masih milik tersangka/terdakwa dengan cara menyetor dan menitipkannya pada kepaniteraan Pengadilan Negeri sehingga secara nyata uang tersebut tidak dapat digunakan selama perjanjian penangguhan masih berlangsung. Uang jaminan penangguhan baru kembali secara riil ke tangan tersangka/terdakwa setelah perjanjian penangguhan penahanan berakhir. Akan tetapi jika tersangka/terdakwa melanggar syarat-syarat yang ditentukan dalam perjanjian berupa tindakan uang jaminan yang dititipkan di kepaniteraan Pengadilan Negeri dengan sendirinya menjadi milik Negara dan disetorkan ke kas Negara oleh panitera bersangkutan. Penyidik, Penuntut Umum dan Hakim berwenang mengadakan penangguhan penahanan atas permintaan tersangka/terdakwa baik dengan jaminan uang atau orang. Aparat penegak hukum dilarang melakukan penyiksaan, pelecehan, serta perampasan terhadap tersangka karena tindakan tersebut merupakan perbuatan melawan hukum yang merendahkan martabat manusia.

\section{SIMPULAN DAN SARAN}

\section{Simpulan}

Persyaratan dan prosedur yang harus dipenuhi pemohon agar dapat dilakukan penangguhan dan penahanan adalah dengan wajib lapor dan tidak keluar rumah dan kota. Dalam PP No. 27 Tahun 1983 tentang Pelaksanaan KUHAP diatur bahwa dalam permintaan penangguhan penahanan, ada jaminan yang disyaratkan yang bisa berupa jaminan uang (Pasal 35) dan jaminan orang (Pasal 36).

Yang menjadi dasar pertimbangan bagi penyidik untuk menangguhkan penahanan dengan jaminan adalah Pasal 31 ayat (1) UU No. 8 Tahun 1981 tentang Hukum Acara Pidana (KUHAP). Jaminan penangguhan penahanan terdapat dalam PP No. 27 Tahun 1983 tersebut ada di dalam Pasal 35 dan Pasal 36 tentang Pelaksanaan Kitab Undang-Undang Hukum Acara Pidana sebagimana terakhir diubah dengan PP No. 58 Tahun 2010. Aparatur penegak hukum yang menurut hukum mempunyai suatu kewajiban untuk memberitahukan serta menjelaskan hak-hak tersangka sebelum menjalani proses hukum acara pidana, seringkali mereka cenderung menghindari kewajibannya tersebut.

Dalam memberikan penangguhan penahanan hendaknya pemerintah atau aparatur penegak hukum memberitahukan serta menjelaskan hak-hak tersangka sebelum menjalani proses hukum acara pidana dan tidak menghindari kewajibannya tersebut yaitu menjelaskan tentang apa saja hak-hak yang dimiliki oleh tersangka/terdakwa dan tidak memberitahukan dengan disertai ancaman (menakut-nakuti) dengan cara yang tidak simpatik. Bagi masyarakat hendaknya selalu mengikut aturan-aturan yang berlaku dalam menjalankan hidup bermasyarakat agar tidak terjerat kasus hukum. Dan untuk pelaku sebaiknya mengikuti prosedur dan persyaratan yang berlaku dalam penangguhan penahanan dengan jaminan sehingga secara materil dan yuridis uang jaminan yang disetor dapat kembali setelah perjanjian penangguhan penahanan berakhir.

\section{Saran}

Besarnya uang jaminan hendaknya ditetapkan sehingga tidak menimbulkan salah penafsiran. Untuk aparatur penegak hukum juga sebaiknya memberitahukan serta menjelaskan hak-hak tersangka sebelum menjalani proses hukum acara pidana dan tidak menghindari kewajibannya tersebut yaitu menjelaskan tentang apa saja hak-hak yang dimiliki oleh tersangka/terdakwa dan tidak memberitahukan dengan disertai ancaman (menakut-nakuti) dengan cara yang tidak simpatik. 


\section{DAFTAR PUSTAKA}

Auliani, N. (2017). Kajian Yuridis Terhadap Penangguhan Penahanan Dengan Jaminan Orang Berdasarkan Pasal 31 Kuhap. Lex Privatum, Vol.5(7).

Ariandi. (2018). Tinjauan Hukum Peminjaman Nama Badan Usaha Cv Dalam Proses Lelang Pengadaan Barang Dan Jasa. Jurnal Fatwa Hukum, Vol.1(1).

Berutu, E. S. (2017). Penangkapan Dan Penahanan Tersangka Menurut Kuhap Dalam Hubungannya Dengan Hak Asasi Manusia. Lex Crimen, Vol.6(6).

Giraldo, M. A. (2020). Kedudukan Penyidik Dalam Prapenuntutan Berdasarkan Kitab UndangUndang Hukum Acara Pidana (KUHAP). Lex Crimen, Vol.9(4).

Hafid, N. (2010). Implementasi Pasal 31 Kuhap Tentang Penangguhan Penahanan Dengan Atau Tanpa Jaminan. Fakultas Hukum, Universitas Muhammadiyah Surakarta.

Harahap, M. Y. (1988). Buku Teks Pembahasan permasalahan dan penerapan KUHAP; Jilid I. Pustaka Kartini, Jakarta.

Hasriady, M., \& Djanggih, H. (2021). ProblematikaProses PenahananDalam Sistem Peradilan Pidana. Kalabbirang Law Journal, Vol.3(1).

Kansil, C. S. T (1989). Pengantar ilmu hukum dan tata hukum Indonesia. Balai Pustaka, Jakarta.

Nurhasan. (2017). Keberadaan Asas Praduga Tak Bersalah Pada Proses Peradilan Pidana. Jurnal Ilmiah Universitas Batam,

Soesilo, R. (2013). Buku Teks Kitab undang-undang hukum pidana (KUHP) serta komentarkomentarnya lengkap pasal d emi pasal. Politeia, Bogor. 